\title{
UJI AKTIVITAS EKSTRAK ETANOL DAN EKSTRAK ETIL ASETAT DAUN SIRIH MERAH (Piper $c f$. fragile. Benth ) TERHADAP PENYEMBUHAN LUKA TERBUKA PADA TIKUS
}

\author{
ACTIVITY ASSAY OF ETHANOL AND ETHYL ACETATE EXTRACT \\ RED BETEL LEAF (Piper $c f$. fragile. Benth) ON THE OPEN WOUND HEALING \\ IN RATS
}

\section{Elly Wardani*, Rizky Arcinthya Rachmania}

Fakultas Farmasi dan Sains

Universitas Muhammadiyah Prof. Dr. Hamka

*Penulis Korespodensi, e-mail: elly.wardanie@gmail.com

\begin{abstract}
ABSTRAK
Luka terbuka adalah luka yang melibatkan robekan pada kulit atau membran mukosa. Apabila terjadi luka dan diabaikan, maka dapat terjadi infeksi. Tanaman obat yang telah diteliti dan dimanfaatkan untuk penyembuhan luka terbuka salah satunya adalah daun sirih merah (Piper cf. fragile, Benth). Penelitian ini akan mengkaji pengaruh ekstrak etanol dan etil asetat daun sirih merah dalam proses penyembuhan luka pada tikus. Hewan coba dibagi menjadi 8 kelompok yaitu kelompok positif (povidon iodine 10\%), negatif, 3 kelompok perlakuan ekstrak etanol daun sirih merah masing-masing dengan konsentrasi $15 \%, 20 \%$ dan $25 \%$ serta 3 kelompok perlakuan ekstrak etil asetat konsentrasi $15 \%, 20 \%$ dan $25 \%$. Luka terbuka dibuat dengan menggunakan metode Morton yang telah dimodifikasi yaitu tikus dicukur bulunya di daerah punggung bagian atas kemudian dibius dengan ketamine pada saat akan dibuat luka berbentuk lingkaran dengan diameter $2 \mathrm{~cm}$. Pemberian ekstrak etanol dan etil asetat daun sirih merah diberikan sekali sehari dengan cara menggunakan syringe sebanyak 0,5 mL/200 g BB tikus. Berdasarkan hasil penelitian yang diperoleh dapat disimpulkan bahwa kelompok ekstrak etanol lebih baik dibandingkan dengan kelompok ekstrak etil asetat dalam menyembuhkan luka terbuka pada tikus.
\end{abstract}

Kata kunci: sirih merah, etanol, etil asetat, luka terbuka

\section{ABSTRACT}

Open wound is a wound that involves a tear in the skin or mucous membranes. If the injury occurs and ignored, it can lead to infection. Medicinal plants that have been studied and used for healing open wounds one of which is red betel leaf (Piper CF. Fragile, Benth). This study will examine the effect of ethanol and ethyl acetate extract of red betel leaf in the process of wound healing in rats. Animals were divided into 8 groups: positive (Povidone-iodine 10\%), negative 3 treatment groups ethanol extract of red betel leaves each with a concentration of 15\%, 20\% and 25\%, and 3 treatment groups ethyl acetate extract concentration of 15\%, 20\% and 25\%. The open wound is made using a modified Morton method that is shaved rats in the upper back area and then drugged with ketamine at the time of a circular wound with a diameter of $2 \mathrm{~cm}$. 
Provision of ethanol and ethyl acetate extract of red betel leaf is given once a day by using a syringe of $0.5 \mathrm{ml} / 200 \mathrm{~g} \mathrm{BB}$ rats. Based on the results obtained can be concluded that the ethanol extract group is better than the group of ethyl acetate extract in healing open wounds in mice.

Key words: red betel, ethanol, ethyl acetate, open wounds

\section{PENDAHULUAN}

Luka merupakan rusaknya sebagian dari jaringan tubuh. Luka sering sekali terjadi dalam aktivitas sehari-hari. Berdasarkan penyebabnya, luka dapat dibagi atas luka karena zat kimia, luka termis, dan luka mekanis. Pada luka mekanis, biasanya luka yang terjadi bervariasi bentuk dan dalamnya sesuai dengan benda yang mengenainya (Sjamsuhidajat, 2004). Berdasarkan status integritas kulit luka dapat dklasifikasikan atas luka terbuka, luka tertutup, luka akut, luka kronik. Luka terbuka adalah luka yang melibatkan robekan pada kulit atau membrane mukosa. Penyebabnya karena trauma oleh benda tajam atau tumpul (insisi bedah, luka tembak) (Potter dan Perry, 2005). Apabila terjadi luka dan diabaikan, maka dapat terjadi infeksi. Mikroorganisme yang ada di sekeliling luka dapat masuk ke dalam tubuh sehingga kulit, jaringan pengikat, otot, syaraf, pembuluh darah, tendon dan selaput tulang dapat dijangkitinya (Prasetyo, 2009).

Tanaman obat yang telah diteliti dan dapat dimanfaatkan untuk penyembuhan luka terbuka salah satunya adalah daun sirih merah. Beberapa penelitian yang telah dilakukan berkaitan dengan manfaat daun sirih merah, yaitu: sebagai antimikroba (Reveny, 2011), antioksidan (Suratmo, 2008) dan antiinflamasi (Subarnas et al., 2010). Pemberian infus daun sirih merah secara topikal menunjukkan efek penyembuhan luka pada tikus diabetes. Penelitian yang telah dilakukan sebelumnya membuktikan bahwa pada konsentrasi $20 \%$ dan $40 \%$ menunjukkan penyembuhan luka pada tikus putih diabetes yang lebih baik dibandingkan dengan pemberian povidone-iodine $10 \%$ (Fimani, 2010).

Daya hambat antimikroba ekstrak daun sirih merah terhadap Staphylococus aureus pada konsentrasi 100\% diperoleh zona hambat 16,3 mm (Kurniawan, 2014). Konsentrasi ekstrak daun sirih merah yang lebih besar menyebabkan diameter zona hambat yang terbentuk di sekeliling kertas cakram juga lebih luas. Hal ini sesuai dengan 
pernyataan bahwa efektivitas suatu zat antibakteri dipengaruhi oleh konsentrasi zat yang diberikan, semakin tinggi konsentrasi semakin tinggi pula bahan aktif sebagai antibakteri sehingga meningkatkan kemampuan daya hambatnya terhadap mikroba (Brooks, 2005). Begitu pula dengan penelitian yang menunjukkan bahwa ekstrak metanol daun sirih merah pada dosis $50 \mathrm{mg} / \mathrm{KgBB}$ memberikan efektivitas antiinflamasi yang paling besar dibandingkan kelompok (Fitriyani, 2011). Adanya flavonoid, tanin dan saponin pada daun sirih merah yang berfungsi sebagai antibakteri dan antiinflamasi akan membantu proses penyembuhan luka, sehingga luka yang terbentuk akan mengalami penyembuhan lebih cepat karena tidak adanya kontaminasi bakteri yang menghambat penyembuhan luka (Kurniawan, 2014; Fitriyani, 2011).

Penelitian ini akan mengkaji pengaruh ekstrak etanol dan etil asetat daun sirih merah dalam proses penyembuhan luka pada tikus. Pada penelitian ini digunakan pelarut etanol dan etil asetat karena pelarut tersebut diharapkan dapat menarik senyawa yang bersifat polar maupun nonpolar. Selain itu, digunakan pembanding berupa larutan povidon iodine yang digunakan sebagai penyembuh luka terbuka.

\section{METODE PENELITIAN}

Alat dan Bahan Penelitian

Alat-alat yang digunakan adalah alat-alat bedah, alat-alat gelas laboratoriun (Pyrex), jangka sorong. Bahan yang digunakan adalah simplisia daun sirih merah. Daun sirih merah (Piper $c f$. fragile, Benth) diperoleh dari Badan Penelitian Tanaman Rempah dan Obat (Balittro), Bogor. Daun sirih merah tua segar dengan kriteria corak putih keabu-abuan dideterminasi di Pusat Penelitian Biologi Lembaga Ilmu Pengetahuan Indonesia (LIPI) Cibinong. Bahan kimia yang digunakan adalah etanol 70\%, etil asetat, ketamin. Bahan pembanding yang digunakan adalah larutan Povidone Iodine (Betadine).

Jalannya Penelitian

Pembuatan ekstrak daun sirih merah

Daun sirih merah segar dicuci bersih dengan air mengalir, kemudian dikeringkan dengan cara diangin-anginkan dan terlindung dari sinar matahari secara langsung untuk 
menghindari rusaknya zat kimia yang terkandung dalam simplisia akibat panas sinar matahari. Tujuan dari pengeringan adalah untuk mengurangi kadar air dalam simplisia sehingga dapat disimpan dalam waktu yang lebih lama. Selain itu pengeringan juga mencegah terjadinya reaksi enzimatik (Voight, 1995). Setelah kering daun sirih merah diserbukkan dengan menggunakan blender lalu diayak dengan pengayak mesh 20. Penyerbukan dilakukan untuk memperluas permukaan simplisia sehingga pelarut dengan mudah menyerap ke dalam simplisia sehingga senyawa aktif yang tertarik lebih maksimal (Voight, 1995). Daun sirih merah yang telah diserbukkan kemudian diekstraksi menggunakan metode maserasi dengan cairan penyari yaitu etanol $70 \%$ dan etil asetat. Tujuan menggunakan 2 cairan penyari adalah untuk membandingkan hasil penyarian terbaik antara etanol $70 \%$ dan etil asetat. Metode maserasi merupakan metode ekstraksi sederhana yang dilakukan dengan cara merendam serbuk simplisia dengan cairan penyari. Keuntungan penyarian dengan metode ini adalah cara pengerjaan dan peralatan yang digunakan sederhana.

Pembuatan ekstrak etanol daun sirih merah

Ekstraksi dilakukan dengan memasukkan 200 g serbuk simplisia ke dalam bejana maserasi kemudian ditambahkan etanol $70 \%$ sampai seluruh serbuk simplisia terendam. Kemudian wadah ditutup rapat dan dibiarkan selama 5 hari disimpan pada suhu ruang dan terlindung dari cahaya. Selama perendaman dilakukan beberapa kali pengadukan. Setelah 5 hari, hasil perendaman disaring dengan menggunakan kertas saring. Ampas yang diperoleh dari penyaringan dimaserasi dengan etanol $70 \%$ dengan prosedur yang sama, maserasi dilakukan sebanyak tiga kali. Alasan pemilihan pelarut etanol $70 \%$ karena pelarut ini merupakan cairan penyari yang umum digunakan untuk menarik zat aktif tanaman. Etanol dapat digunakan sebagai bahan pengawet untuk mencegah pertumbuhan jamur, bakteri, kapang, dan lain-lain. Cairan penyari etanol $70 \%$ mengandung $70 \%$ etanol dan 30\% air. Cairan penyari akan menembus dinding sel dan masuk ke dalam rongga sel yang mengandung zat aktif, sehingga zat aktif terlarut. Adanya perbedaan konsentrasi tersebut maka zat aktif dapat terus keluar sampai terjadi keseimbangan di dalam dan di luar sel (Voight, 1995). 
Untuk menentukan akhir maserasi dilakukan dengan cara organoleptis, seperti warna dan pemeriksaan zat aktif secara kualitatif pada maserat terakhir. Maserat yang diperoleh dipekatkan dengan vacuum rotary evaporator pada suhu $50^{\circ} \mathrm{C}$ hingga diperoleh ekstrak kental. Ekstrak kental yang diperoleh dikeringkan dengan menggunakan oven pada suhu $50^{\circ} \mathrm{C}$. Pemekatan bertujuan untuk menaikkan kandungan ekstrak daun sirih merah dengan mengurangi kadar air dan mengurangi sisa pelarut pada saat proses maserasi.

Pembuatan ekstrak etil asetat daun sirih merah

Serbuk daun sirih merah ditimbang sebanyak $500 \mathrm{~g}$, dimasukkan ke dalam bejana maserasi, kemudian ditambahkan $5 \mathrm{~L}$ etil asetat secara bertahap lalu direndam selama 6 jam pertama sambil sekali-sekali diaduk kemudian didiamkan selama 24 jam. Kemudian disaring, ampas dimaserasi kembali dengan etil asetat (lebih kurang 3 kali perlakuan). Maserasi dilakukan selama 5 hari disimpan pada suhu ruang dan terlindung dari cahaya. Setelah 5 hari hasil perendaman disaring dengan menggunakan kertas saring. Alasan etil asetat dipilih karena pelarut tersebut bersifat semipolar, tidak beracun dan volatil terhadap pemanasan, sehingga diharapkan dapat menarik senyawa-senyawa semipolar.

Untuk menentukan akhir maserasi, dilakukan uji dengan identifikasi ampas sampai tidak terkandung zat aktifnya secara kualitatif pada maserat terakhir dan organoleptis seperti warna. Semua filtrat disatukan dan dipekatkan dengan menggunakan vacuum rotary evaporator pada suhu $50^{\circ} \mathrm{C}$ hingga diperoleh ekstrak kental. Ekstrak kental dikeringkan menggunakan oven pada suhu $50^{\circ} \mathrm{C}$ (Depkes RI, 2008).

Penapisan fitokimia ekstrak etanol dan etil asetat daun sirih merah

a. Identifikasi alkaloid (Depkes RI (b), 1995)

Sebanyak 500 mg ekstrak kering dimasukkan dalam tabung reaksi, ditambahkan 1 $\mathrm{ml} \mathrm{HCl} 2 \mathrm{~N}$ dan $9 \mathrm{ml}$ akuades, dipanaskan di atas penangas air pada suhu $100^{\circ} \mathrm{C}$ selama 2 menit, didinginkan dan disaring. Kemudian dibagi menjadi 2 tabung reaksi. Tabung pertama diberi pereaksi Dragendorf, jika terbentuk endapan merah menunjukkan adanya 
alkaloid. Tabung kedua diuji dengan pereaksi Meyer, terbentuk endapan putih menunjukkan adanya alkaloid.

b. Identifikasi flavonoid (Depkes RI (b), 1995)

Sebanyak 500 mg ekstrak kering dimasukkan ke dalam tabung reaksi, ditambahkan $5 \mathrm{~mL}$ etanol, dikocok dan disaring. Sebanyak $1 \mathrm{~mL}$ filtrat dimasukkan ke dalam tabung, ditambahkan 2 tetes $\mathrm{HCl}$ pekat dan $200 \mathrm{mg}$ logam $\mathrm{Mg}$. Perubahan warna menjadi merah coklat menunjukkan adanya flavonoid.

c. Identifikasi saponin (Depkes RI (b), 1995)

Sebanyak 500 mg ekstrak kering dimasukkan ke dalam tabung reaksi, ditambahkan $10 \mathrm{ml}$ air panas, didinginkan dan dikocok kuat selama 10 detik, terbentuk buih yang stabil selama tidak kurang dari 10 menit setinggi 1-10 cm. Penambahan 1 tetes $\mathrm{HCl} 2 \mathrm{~N}$, buih tidak hilang, maka menunjukkan adanya saponin.

d. Identifikasi tanin (Depkes RI (b), 1995)

Sebanyak 500 mg ekstrak kering dimasukkan ke dalam tabung reaksi, ditambahkan $100 \mathrm{~mL}$ air suling, dididihkan selama 15 menit di atas penangas air pada suhu $100^{\circ} \mathrm{C}$, kemudian didinginkan lalu disaring dengan kertas saring. Filtrat diambil kemudian ditambahkan 1-2 tetes $\mathrm{FeCl}_{3} 1 \%$, terbentuk warna biru tua atau hijau kehitaman menunjukkan adanya tanin.

1. Pemeriksaan mutu ekstrak etanol dan etil asetat daun sirih merah

a. Pemeriksaan organoleptik (Depkes RI (b), 1995)

Pemeriksaan organoleptik dilakukan secara analisis kualitatif. Pemeriksaan organoleptic antara lain pemeriksaan bentuk, warna, bau, dan rasa ekstrak etanol dan etil asetat daun sirih merah.

b. Penetapan susut pengeringan (Depkes RI, 2008)

Ekstrak kering ditimbang seksama sebanyak 1 hingga $2 \mathrm{~g}$ dalam botol timbang bertutup yang sebelumnya telah dipanaskan pada suhu $105^{\circ} \mathrm{C}$ dan ditara. Ekstrak diratakan dalam botol timbang dengan menggoyangkan botol, hingga tebal lapisan kurang lebih 5-10 mm. Ekstrak dimasukkan ke dalam eksikator, tutupnya dibuka dan dikeringkan pada suhu yang sudah ditetapkan hingga mendapat bobot yang tetap. Setiap sebelum pengeringan, botol dibiarkan dalam keadaan tertutup mendingin dalam eksikator hingga suhu ruang. 
c. Rendemen

Perhitungan rendemen dilakukan dengan menghitung jumlah ekstrak kering yang didapat terhadap jumlah serbuk kering sebelum dilakukan ekstraksi kemudian dikalikan 100\% (Depkes RI, 2000), seperti terlihat pada persamaan 1.

Rendemen $=\underline{\text { Bobot Ekstrak Kering Daun Sirih Merah }} \times 100 \%$

Bobot serbuk Kering Daun Sirih merah

\section{Rancangan Penelitian}

Rancangan penelitian yang digunakan adalah rancangan acak lengkap. Tikus dibagi menjadi 8 kelompok perlakuan, masing-masing kelompok terdiri dari 4 ekor tikus. Pengelompokkan hewan uji dihitung berdasarkan rumus Federer (Hanafiah, 1993).

\section{Persiapan Hewan Uji}

Tikus putih jantan diaklimatisasi selama 7 hari. Tikus yang diikut sertakan adalah tikus yang sehat, mata yang jernih dan bulu yang bersih. Tikus yang digunakan dalam percobaan sebanyak 32 ekor. Tikus diberi minum dan pakan standar. Tiap kelompok tikus ditempatkan pada kandang yang terpisah. Tiap kandang berisi 4 ekor tikus. Kandang diletakkan pada ruang tertutup dengan sirkulasi udara dan penerangan yang cukup.

\section{Penetapan Dosis}

Konsentrasi ekstrak etanol dan etil asetat daun sirih merah yang digunakan berdasarkan penelitian yang sebelumnya yaitu konsentrasi efektif rebusan daun sirih merah 40\% (Fimani, 2010). Berdasarkan konsentrasi tersebut maka akan dibuat menjadi 3 variasi konsentrasi yang berbeda yaitu : 15, 20 dan $25 \%$ b/v. Bahan pembanding yang digunakan pada penelitian ini adalah Betadin ${ }^{\circledR}$ (povidon iodium) dengan konsentrasi $10 \%$. 
5. Penentuan efek penyembuhan luka.

Percobaan penentuan efek penyembuhan luka dilakukan dengan menggunakan metode Morton yang telah dimodifikasi.Tikus dicukur terlebih dahulu di daerah punggung bagian atas (dilakukan sehari sebelum pembuatan luka). Pada saat akan dibuat luka, tikus dibius terlebih dahulu dengan ketamine 40,08 mg/kg BB tikus secara intramuskular. Setelah itu daerah punggung bagian atas dan sekitarnya dibersihkan dengan etanol $70 \%$. Lalu dibuat luka berbentuk lingkaran dengan diameter $\pm 2,5 \mathrm{~cm}$, kemudian dibedah sampai bagian subkutis, yaitu sampai bagian panniculus carnosus dan jaringan yang terikat dengannya. Pemberian ekstrak etanol maupun etil asetat daun sirih merah untuk masing-masing variasi dosis dilakukan satu kali sehari untuk masingmasing konsentrasi $(2 \%, 14 \%$, dan $8 \%$ ) sebanyak $0,5 \mathrm{~mL}$. Sediaan larutan uji ekstrak etanol dan etil asetat daun sirih merah dibuat dari ekstrak kering etanol maupun etil asetat dilarutkan dengan akuades steril. Pemberian povidon iodium $10 \%$ sebanyak 0,5 $\mathrm{mL}$ sebagai kontrol positif dilakukan satu kali sehari hingga menutupi luka. Pemberian dilakukan setiap hari dimulai satu hari setelah luka dibuat, selama 15 hari. Perincian pembagian kelompok terdiri dari 8 kelompok dengan masing-masing kelompok terdiri dari 4 ekor. Perlakuan tiap kelompok adalah sebagai berikut :

Kelompok I : Kontrol positif, kelompok yang dibuat luka serta diberikan pembanding Betadin ${ }^{\circledR}$ (povidon iodium) 10\%selama 15 hari .

Kelompok II : Kontrol negatif, kelompok yang dibuat luka tanpa pemberian sediaan uji.

Kelompok III : Kelompok uji 1, kelompok yang dibuat luka serta diberikan ekstrak etanol konsentrasi 15\%, 1x sehari selama 15 hari.

Kelompok IV : Kelompok uji 2, kelompok yang dibuat luka serta diberikan ekstrak etanol konsentrasi 20\%, 1x sehari selama 15 hari.

Kelompok V : Kelompok uji 3, kelompok yang dibuat luka serta diberikan ekstrak etanol konsentrasi 25\%, 1x sehari selama 15 hari.

Kelompok VI : Kelompok uji 4, kelompok yang dibuat luka serta diberikan ekstrak etil asetat konsentrasi 15\%, 1x sehari selama 15 hari.

Kelompok VII : Kelompok uji 5, kelompok yang dibuat luka serta diberikan ekstrak etil asetat konsentrasi 20\%, , 1x sehari selama 15 hari 
Kelompok VIII : Kelompok uji 6, kelompok yang dibuat luka serta diberikan ekstrak etil asetat konsentrasi 25\%,, 1x sehari selama 15 hari.

Pemberian ekstrak etanol dan etil asetat daun sirih merah diberikan sekali sehari dengan cara menggunakan syringe sebanyak $0,5 \mathrm{ml} / 200 \mathrm{~g}$ BB tikus. Pemberian sediaan uji dilakukan dengan cara dioleskan secara merata pada luka.

a. Luas daerah luka dan persentase penyembuhan luka diamati dengan cara mengukur rata-rata diameter luka yang diukur pada arah vertikal, horizontal, dan kedua diagonal.

b. Data penelitian yang diperoleh, ditabulasi, dibuat rata-rata kemudian dianalisis secara statistik.

6. Pengamatan Percobaan (Morton dan Malone, 1972)

Pengamatan dilakukan dengan persentase penyembuhan luka dengan cara mengukur rata-rata diameter luka yang diukur pada arah vertikal, horizontal, dan kedua diagonal.

Persentase penyembuhan luka dihitung dengan rumus 2 .

$$
\frac{\mathrm{d} 1^{2}-\mathrm{d} 2^{2}}{\mathrm{~d} 1^{2}} \times 100 \%
$$

Keterangan:

d1 : diameter luka sehari setelah pembuatan luka

d2 : diameter luka pada hari dilakukan pengamatan

Analisis Data

Data yang diperoleh berupa data diameter luka dan persentase penyembuhan luka. Data dianalisis dengan menggunakan program pengolah statistik dan dilakukan terlebih dahulu uji normalitas dan homogenitasnya. pengolahan data secara statistik KolmogrovSmirnov Test dan Test of Homogeneity of Variance. Jika data normal dan homogen selanjutnya dilakukan uji anova dua arah dengan taraf signifikansi 95\% untuk melihat pengaruh dari pelakuan. Untuk mengetahui lebih lanjut adanya perbedaan antar kelompok dilakukan uji Tukey (Priyatno, 2012).

\section{HASIL DAN PEMBAHASAN}

Hasil rendemen dan susut pengeringan ekstrak etanol $70 \%$ dan etil asetat dapat dilihat pada Tabel I. 
Tabel I. Hasil Rendemen dan Susut pengeringan

\begin{tabular}{lcc}
\hline \multicolumn{1}{c}{ Jenis } & \multicolumn{2}{c}{ Hasil (\%) } \\
\cline { 2 - 3 } & Rendemen & $\begin{array}{c}\text { Susut } \\
\text { pengeringan }\end{array}$ \\
\hline Ekstrak etanol 70\% daun sirih merah & $11,36 \%$ & $3,98 \%$ \\
Ekstrak etil asetat daun sirih merah & $7,13 \%$ & $4,82 \%$ \\
\hline
\end{tabular}

Tahap selanjutnya adalah uji penapisan fitokimia ekstrak etanol 70\% dan ekstrak etanol dan etil asetat daun sirih merah. Uji penapisan fitokimia dilakukan untuk mengetahui senyawa metabolit sekunder yang terkandung dalam ekstrak etanol dan etil asetat daun sirih merah. Hasil penapisan fitokimia menunjukkan bahwa ekstrak etil asetat mengandung alkaloid, saponin dan steroid. Hasil penapisan ekstrak etanol mengandung alkaloid, flavonoid, saponin, tannin, triterpenoid dan steroid. Hasil penapisan fitokimia dapat dilihat pada Tabel II.

Tabel II. Hasil Penapisan Fitokimia ekstrak etanol dan etil asetat

\begin{tabular}{lcc}
\hline Metabolit sekunder & Ekstrak etanol 70\% & Ekstrak Etil Asetat \\
\hline Alkaloid & + & + \\
Flavonoid & + & - \\
Saponin & + & + \\
Tanin & + & - \\
Triterpenoid & + & - \\
Steroid & + & + \\
\hline
\end{tabular}

Keterangan : $(+)=$ Positif

$(-)=$ Negatif

Povidon iodine merupakan agen antimikroba paten yang digunakan secara luas dan efektif dalam desinfeksi dan pembersihan kulit baik pra-maupun pasca operasi, dalam penatalaksanaan luka traumatik yang kotor pada pasien rawat jalan dan untuk mengurangi sepsis luka pada luka bakar. Povidon iodine memiliki toksisitas rendah pada jaringan, biasanya digunakan dengan konsentrasi penuh baik dioles maupun kompresan. Dalam povidon iodine konsentasi $10 \%$ mengandung $1 \%$ iodine yang mampu membunuh bakteri dalam 1 menit dan spora dalam waktu 15 menit (Morison, 2003). Obat ini digunakan sebagai antiseptik berspektrum luas dan menggantikan 
merkurokrom serta iodium tingtur karena sifatnya yang tidak iriatif (Maryunani, 2013). Pengujian aktivitas penyembuhan luka terbuka dilakukan dengan metode morton yang telah dimodifikasi (Verawati, 2015).

Persentase penyembuhan luka diamati dari luas daerah luka. Diameter awal yang menjadi dasar perhitungan persentase penyembuhan luka adalah diameter sehari setelah tikus dilukai (hari ke-1), bukan hari pada saat tikus dilukai (hari ke-0). Hal ini disebabkan ketidakstabilan luka selama 24 jam setelah tikus dilukai. Pada 12 jam pertama luka berubah ukuran secara drastis, sedangkan antara jam ke-12 sampai jam ke24 hanya berubah sedikit dan akhirnya menjadi stabil. Luka berubah bentuk dari lingkaran menjadi bulat telur, dimana diameter horizontal mengecil sedangkan diameter vertikal, diagonal kiri dan diagonal kanan membesar. Perubahan bentuk luka ini disebabkan karena tikus dilukai di daerah punggung dekat bahu, karena tikus sangat aktif bergerak sehingga luka menjadi tertarik. Selain itu diketahui bahwa kulit normal mempunyai tegangan dan apabila dilakukan pemotongan kulit yang tebal, maka akan diperoleh luka yang lebih besar dari potongan kulit yang dibuang (Magdalena, 1993). Rata-rata diameter luka terbuka tiap kelompok dapat dilihat pada Tabel III. Hubungan antara persentase penyembuhan luka terbuka terhadap waktu dapat dilihat pada Gambar 1.

Tabel III. Rata-rata diameter luka terbuka tiap kelompok (cm)

\begin{tabular}{lcccccccr}
\hline \multicolumn{1}{c}{ Kelompok } & \multicolumn{8}{c}{ Diameter $(\mathbf{c m})$ hari ke- } \\
& $\mathbf{1}$ & $\mathbf{3}$ & $\mathbf{5}$ & $\mathbf{7}$ & $\mathbf{9}$ & $\mathbf{1 1}$ & $\mathbf{1 3}$ & $\mathbf{1 5}$ \\
\hline Kontrol positif & 2,23 & 1,96 & 1,83 & 1,68 & 1,44 & 0,90 & 0,75 & 0,48 \\
Kontrol negatif & 2,42 & 2,20 & 2,14 & 1,95 & 1,81 & 1,58 & 1,38 & 1,05 \\
Uji 1 (ekstrak etanol 15\%) & 2,67 & 2,36 & 2,10 & 1,71 & 1,27 & 0,97 & 0,67 & 0,55 \\
Uji 2 (ekstrak etanol 20\%) & 2,45 & 2,25 & 1,93 & 1,75 & 1,17 & 0,87 & 0,63 & 0,48 \\
Uji 3 (ekstrak etanol 25\%) & 2,45 & 2,20 & 1,86 & 1,60 & 1,18 & 0,85 & 0,63 & 0,21 \\
Uji 4 (ekstrak etil asetat 15\%) & 2,43 & 2,15 & 1,90 & 1,78 & 1,27 & 1,07 & 0,78 & 0,54 \\
Uji 5 (ekstrak etil asetat 20\%) & 2,34 & 2,06 & 1,93 & 1,66 & 1,22 & 1,02 & 0,78 & 0,55 \\
Uji 6 (ekstrak etil asetat 25\%) & 2,15 & 1,97 & 1,78 & 1,60 & 1,18 & 0,85 & 0,63 & 0,29 \\
\hline
\end{tabular}


Tabel IV. Rata-rata persentase penyembuhan luka terbuka tiap kelompok

\begin{tabular}{lcccccccc}
\hline Kelompok & \multicolumn{8}{c}{ Penyembuhan luka (\%) hari ke- } \\
& $\mathbf{1}$ & $\mathbf{3}$ & $\mathbf{5}$ & $\mathbf{7}$ & $\mathbf{9}$ & $\mathbf{1 1}$ & $\mathbf{1 3}$ & $\mathbf{1 5}$ \\
\hline Kontrol positif & 0,00 & 20,95 & 30,62 & 40,20 & 57,71 & 82,82 & 87,32 & 95,25 \\
Kontrol negative & 0,00 & 16,90 & 21,63 & 34,76 & 44,34 & 56,96 & 66,92 & 80,70 \\
Uji 1 (ekstrak etanol 15\%) & 0,00 & 21,85 & 37,17 & 59,11 & 77,50 & 86,88 & 93,69 & 95,83 \\
Uji 2 (ekstrak etanol 20\%) & 0,00 & 16,71 & 36,06 & 47,73 & 76,75 & 87,35 & 93,42 & 96,26 \\
Uji 3 (ekstrak etanol 25\%) & 0,00 & 18,97 & 41,22 & 55,54 & 76,61 & 87,59 & 93,00 & 98,90 \\
Uji 4 (ekstrak etil asetat 15\%) & 0,00 & 21,22 & 39,04 & 46,86 & 72,76 & 80,00 & 89,62 & 94,63 \\
Uji 5 (ekstrak etil asetat 20\%) & 0,00 & 22,64 & 31,78 & 49,50 & 72,89 & 81,12 & 88,53 & 93,91 \\
Uji 6 (ekstrak etil asetat 25\%) & 0,00 & 15,95 & 30,91 & 44,06 & 66,45 & 82,90 & 89,22 & 97,61 \\
\hline
\end{tabular}

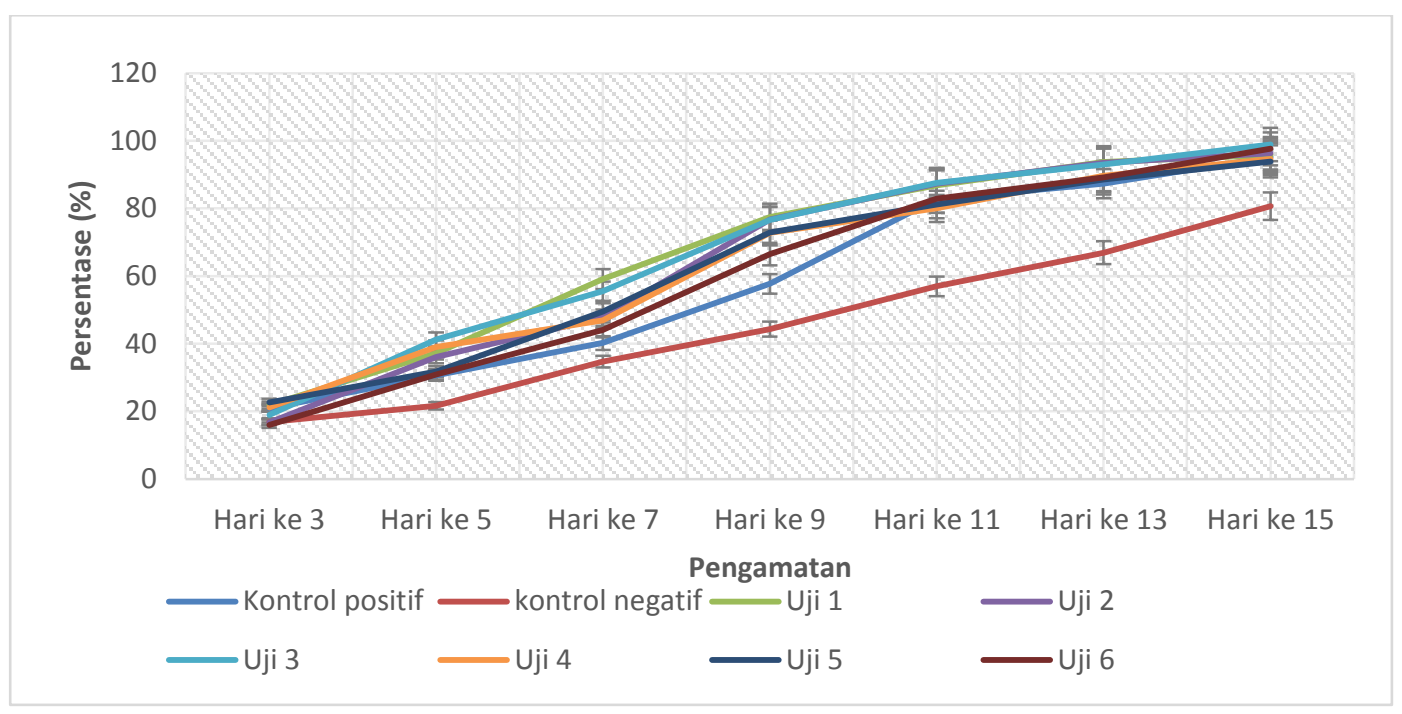

Gambar 1. Grafik persentase penyembuhan luka terbuka terhadap waktu

Data yang diperoleh berupa persentase penyembuhan luka yang terbentuk terhadap waktu penyembuhan diuji secara statistik untuk mengetahui apakah data sudah terdistribusi secara normal dan homogen. Setelah diketahui data sudah terdistribusi normal dan homogen kemudian dilanjutkan dengan uji ANOVA dua arah (two way). Untuk mengetahui perbedaan bermakna antar kelompok dilanjutkan dengan uji tukey (Priyatno 2012).

Hasil pengolahan data secara statistik Kolmogrov-Smirnov Test didapat nilai sig. $(0,149)>\alpha(0,05)$ dan pada Test of Homogeneity of Variance didapat nilai sig. $>\alpha(0,05)$ uji kedunya menunjukkan data antar kelompok terdistribusi secara normal dan homogen. Hasil uji ANOVA dua arah (two way) menunjukkan nilai sig. $<\alpha(0,05)$ 
berarti terdapat perbedaan yang bermakna antara kelompok uji dan hari terhadap persentase penyembuhan luka. Terakhir data dapat dilanjutkan dengan uji tukey. Hasil uji tukey menunjukkan bahwa terdapat perbedaan bermakna antara kelompok kontrol negatif dengan kelompok kontrol positif dan kelompok perlakuan uji I, II, III, IV, V dan VI. Dapat disimpulkanan bahwa pada kelompok IV, VI, VII dan VIII tidak ada perbedaan dengan kelompok I (kontrol positif), sedangkan kelompok III dan V memiliki perbedaan bermakna dengan kelompok I (kontrol positif). Hal ini menunjukkan peranan ekstrak etanol konsentrasi $15 \%$ dan 25\% memiliki persentase penyembuhan luka lebih tinggi daripada kelompok kontrol positif (pembanding). Begitu pula jika dibandingkan antara kelompok perlakuan ekstrak etanol dengan etil asetat, dapat dikatakan bahwa kelompok esktrak etanol lebih baik dibandingkan dengan etil asetat ditinjau dari persentase penyembuhan luka. Pada hasil uji ANOVA dua arah (two way) menunjukkan bahwa terdapat perbedaan bermakna setiap dua hari pengamatan luka sehingga dapat disimpulkan bahwa hari ke-15 merupakan hari paling optimum dalam penyembuhan luka tebuka.

Proses penyembuhan dibagi menjadi 3 fase yaitu fase inflamasi, fase poliferasi dan fase maturasi (Syamsuhidayat, 2011). Pada fase inflamasi terjadi peningkatan aliran darah ke daerah luka. Bersamaan dengan aliran darah, terjadi juga aliran fibrin untuk menutup pembuluh darah yang luka dan melindungi adanya infeksi bakteri. Pada fase ini juga terjadi pengerahan sel darah putih, monosit dan makrofag yang berfungsi untuk memfagositosit mikroorganisme dan sisa sel-sel mati. Proses inflamasi pada penelitian ini mengakibatkan luka sedikit bengkak dan kemerahan yang berlangsung kira-kira selama 1-3 hari, hal ini sesuai dengan penelitian yang menyebutkan bahwa proses inflamasi berlangsung segera setelah luka terjadi dan berakhir 3-4 hari (Syamsuhidayat, 2011). Proses inflamasi dari tiap kelompok perlakuan menunjukkan ciri yang berbedabeda dimana kelompok normal dan kontrol negatif tidak hanya menunjukkan kemerahan, panas, edema (bengkak) dan rasa sakit namun juga ditemukan nanah yang disebabkan reaksi inflamasi akut terhadap bakteri (piogenik) (Bratawidjaja, 2006). Hal tersebut dikarenakan kelompok normal dan kontrol negatif tidak diberikan antiseptik maupun antibakteri, sedangkan pada kelompok kontrol positif serta kelompok III sampai dengan VIII tidak menunjukkan ciri adanya nanah. 
Fase berikutnya adalah fase proliferasi. Fase ini umumnya berlangsung pada hari ke-3 atau hari ke-4 sampai hari ke-21. Pada fase ini fibroblast membentuk kolagen dan jaringan ikat, disini juga terjadi pembentukan kapiler baru yang dimulai saat terjadi peradangan (Syamsuhidayat, 2011). Proses ini menandakan terjadinya kesembuhan yang dimulai dari adanya pertumbuhan kapiler dan pertumbuhan jaringan granula yang dimulai dari dasar luka. Luka akan berkembang menjadi scab (keropeng) yang terdiri dari plasma dan protein yang bercampur dengan sel-sel mati. Tanda-tanda yang dapat diamati dengan jelas pada penelitian ini adalah terjadinya warna merah dan adanya jaringan granulasi. Pada fase ini luka terlihat seperti garis kuning yang menandakan sedang terjadi proses epitelisasi.

Pada kelompok kontrol positif (povidon iodine 10\%), kelompok uji III, IV, V, VI, VII dan VIII menunjukkan aktivitas dalam penyembuhan luka terbuka lebih cepat dibandingkan kelompok kontrol negatif. Pada penelitian ini, kesembuhan luka untuk masing-masing kelompok perlakuan ditandai dengan munculnya warna merah pada permukaan luka dimulai pada hari ke-4. Hal ini menunjukkan adanya tanda penyembuhan yang baik karena proses angiogenesis berlangsung dengan sempurna dan tidak ada infeksi mikroorganisme dan lainnya.

Fase selanjutnya adalah fase maturasi yang dimulai pada minggu ketiga dan berakhir sampai kurang lebih 12 bulan. Fibroblast sudah mulai meninggalkan jaringan granulasi, warna kemerahan pada luka mulai berkurang karena pembuluh mulai beregresi dan serat fibrin dari kolagen bertambah banyak untuk memperkuat jaringan parut. Pada fase ini peran kolagen sangatlah penting dimana bila produksi kolagen berlebih maka akan terjadi penebalan jaringan parut dan sebaliknya bila berkurang maka akan terjadi penurunan kekuatan jaringan parut dan luka akan selalu terbuka (Syamsuhidayat, 2011). Hasil penelitian ini menunjukkan bahwa pemberian ekstrak etanol dan etil asetat daun sirih merah secara topikal pada luka tikus dapat memperpendek fase inflamasi dan fase proliferasi seperti yang diuraikan di atas.

Kelompok perlakuan ekstrak etanol lebih baik dibandingkan dengan kelompok perlakuan etil asetat terutama pada konsentrasi ekstrak etanol 15\% dan 25\% memiliki aktivitas lebih tinggi dibandingkan dengan kelompok positif (pembanding). Hal ini mungkin disebabkan karena kandungan yang terdapat dalam ekstrak etanol mengandung flavonoid, tannin, saponin, alkaloid, steroid dan triterpenoid yang 
memiliki peranan dalam mempercepat penyembuhan luka terbuka. Pada uji penapisan fitokimia ekstrak etil asetat daun sirih merah menunjukkan adanya senyawa metabolit sekunder berupa alkaloid, steroid dan saponin.

Adanya senyawa flavonoid inilah yang membuat proses inflamasi berlangsung lebih singkat sehingga penyembuhan jaringan berupa reepitelisasi akan terjadi lebih dini (Sulistiawati dan Nuraini, 2011). Senyawa tanin juga berperan dalam proses penyembuhan luka karena tanin memiliki sifat astrigen yang akan menyebabkan berkurangnya permeabilitas mukosa dan memperkuat ikatan antar mukosa sehingga mikroorganisme dan zat kimia iritan tidak dapat masuk ke dalam luka (Suprapto, 2012). Senyawa tanin juga mampu menghambat hipersekresi cairan mukosa dan menetralisir protein inflamasi (Suprapto, 2012). Tanin memiliki afinitas terhadap protein sehingga dapat terkonsentrasi pada area luka. Tanin juga memiliki aktivitas hemostatik dengan mengubah protein tertentu yang larut menjadi tidak larut karena adanya ikatan kimia yang berkembang di dalamnya, dimana kelompok phenolic hydroxyl mampu bereaksi dengan hydrogen terikat kuat dengan atom protein yang mengikat peptide yang dapat meningkatkan kekentalan darah dan menghambat pergerakan sel darah merah, hal inilah yang memfasilitasi agregrat (Daugnon et al., 2012).

Senyawa saponin memiliki peran meningkatkan respon sel imun (Hoffmann, 2003) hal ini sesuai dengan penelitian yang menyatakan bahwa senyawa saponin dapat meningkatkan sistem kekebalan tubuh, mengoptimalkan kadar gula dalam darah dan mengurangi penggumpalan darah (Prasetyo et al., 2010). Senyawa saponin juga membantu merangsang pembentukan sel epitel yang baru dan mendukung proses reepitelisasi, semakin cepat proses reepitelisasi maka akan mempercepat proses penyembuhan luka dan dapat meningkatkan pembentukan pembuluh darah (Morisaki et al., 1995).

Proses penyembuhan infeksi kulit juga dipengaruhi oleh keadaan fisiologis dari hewan uji, karena kulit merupakan barier fisik yang dapat mempertahankan tubuh dari agen patogen. Apabila terdapat kerusakan kulit, maka kulit akan mempertahankan tubuh dengan proses imunologik yang cepat terhadap agen patogen tersebut dan mengeluarkan mikroorganisme tersebut dari epidermis dan dermis (Muntiaha et al., 2014). Hal inilah yang membuat kelompok kontrol negatif yakni luka yang dibiarkan saja dan tidak diberi sediaan juga mengalami kesembuhan sama seperti kelompok kontrol positif dan 
kelompok uji yang diberi ekstrak etanol dan etil asetat daun sirih merah, hanya saja waktu penyembuhan kelompok kontrol negatif tidaklah secepat kelompok kontrol positif dan kelompok sediaan uji ekstrak etanol dan etil asetat daun sirih merah. Adanya senyawa metabolit sekunder berupa flavonoid, tanin dan saponinlah yang berperan dalan percepatan penyembuhan luka terbuka.

\section{KESIMPULAN}

Kelompok ekstrak etanol lebih baik dibandingkan dengan kelompok ekstrak etil asetat dalam menyembuhkan luka terbuka pada tikus. Kelompok ekstrak etanol konsentrasi $15 \%$ dan $25 \%$ daun sirih merah memiliki aktivitas dalam mempercepat penyembuhan luka terbuka lebih tinggi dibandingkan dengan kelompok kontrol positif yang diberi povidon iodine konsentrasi $10 \%$ pada tikus putih (Rattus norvegicus) jantan galur Sprague dawley (SD).

\section{UCAPAN TERIMA KASIH}

Ucapan terima kasih ditujukan kepada Lembaga Penelitian dan Pengembangan Universitas Muhammadiyah Prof. Dr. Hamk a yang telah membiayai penelitian Internal dengan No. Kontrak : 167/F.03.07/2016.

\section{DAFTAR PUSTAKA}

Bratawidjaja, Karnen G., 2006, Imunologi Dasar Edisi ke-7. UI Press. Jakarta. Hlm 140.

Departemen Kesehatan RI., 1995, Materia Medika Indonesia. Jilid VI. Jakarta: Direktorat Jenderal Pengawasan Obat dan Makanan: 326, 333-337.

Departemen Kesehatan RI,. 2008, Farmakope Herbal Indonesia. Edisi I. Jakarta: Direktorat Jenderal Pengawasan Obat dan Makanan : 171-174.

Dougnon T V, Klotoe J R, Segbo J, et al., 2012, Evaluation of The Phytochemical and Hemostatic Potential of Jatropha multifida Sap. Dalam : American Journal of Pharmacy and Pharmacology, ( 6).

Fimani A., 2010, Pengaruh Pemberian Infusa Daun Sirih Merah (Piper cf.fragile, Benth) Secara Topikal Terhadap Penyembuhan Luka Pada Tikus Putih Diabet, Skripsi, Departemen Farmasi Fakultas Matematika dan Ilmu Pengetahuan Alam Universitas Indonesia, Depok : 37. 
Fitriyani Atik, 2011, Uji Antiinflamasi Ekstrak Metanol Daun Sirih Merah (Piper Crocatum Ruiz \& Pav) Pada Tikus Putih, Majalah Obat Tradisional, Jember: 2.

Hanafiah KA., 2001, Rancangan Percobaan: Teori dan Aplikasi. Edisi Revisi. Penerbit Raja Grafindo Persada. Jakarta: 45.

Hoffmann David., 2003, Medical Herbalism : The Science and Pratice of Herbal Medicine. Vermont. Healing Arts Press.

Kurniawan S.W., 2014, Uji Efektifitas Ekstrak Daun Sirih Merah (Piper crocatum) Terhadap Staphylococcus Aureus dan Salmonella Typhi, Skripsi, Universitas Lampung : 2 .

Magdalena E., 1993, Efek Ekstrak Daun Bandotan Terhadap Luka Terbuka pada Tikus Putih, Skripsi, Jurusan Farmasi Universitas Indonesia.

Morison M.J., 2003, Menejemen Luka alih bahasa Tyasmono A.F. EGC. Jakarta: 68.

Morton JJP, Malone MH., 1972, Evaluation of Vulnerary by An Open Wound Procedure in Rats. Archive International Pharmacodyn. 196: 117-128

Morisaki N, Watanabe S,Tezuka M, Zenibayashi M, Shiina R,Koyama N, Kanzaki T, Saito Y,1995. Mechanism of Angiogenic Effects of Saponin from Gingseng Radix Rubra in Human Umblical Vein Endothelial Cells. Dalam : Br J Pharmacol. 115 (7) : $1188-1193$.

Muntiaha M Ch, Yamlean P V Y, Astuti W L., 2014, Uji Efektivitas Sediaan Krim Getah Jarak Cina (Jatropha multifida L.) untuk Pengobatan Luka Sayat yang Terinfeksi Bakteri Staphylococcus aureus pada Kelinci (Orytolagus cuniculus). Dalam : Jurnal Ilmiah Farmasi UNSRAT, (3) 3.

Priyatno D., 2012, Belajar Praktis Analisis Parametrik dan Non Parametrik dengan SPSS. Penerbit Gava Media, Yogyakarta: 64-73.

Potter, A, P dan Perry, G, A., 2005, Buku Ajar Fundamental Keperawatan: Konsep, Proses, dan Praktik. EGC. Jakarta: 1852-1898.

Prasetyo, B., 2009, Efektivitas Getah Jarak Cina (Jatropha multifida L.) Terhadap Penyembuhan Luka Perdarahan Kapiler pada Marmut, Skripsi, Universitas Islam Sultan Agung Semarang.

Prasetyo BF, Wientarsih I, Priosoeryanto BP., 2010, Aktivitas Sediaan Gel Ekstrak Batang Pohon Pisang Ambon dalam Proses Penyembuhan Luka Pada Mencit. Dalam : Jurnal veteriner 11 (2) : 70-73.

Reveny J., 2011, Daya Antimikroba Ekstrak dan Fraksi Daun Sirih Merah (Piper betle Var.Rubrum). Dalam: Jurnal Ilmu Dasar, 12(1): 6-12. 
Sjamsuhidajat R, Wim de Jong., 2004, Buku Ajar Ilmu Bedah, Edisi 2, EGC. Jakarta: 67-68.

Subarnas A, Yasmiwar S, Elis M., 2010, Aktivitas Antiinflamasi Ekstrak Etanol Daun Sirih Merah (Piper betle Var.Rubrum) pada Tikus Putih Jantan, Skripsi, Fakultas Farmasi Universitas Padjajaran, Bandung. http://farmasi.unpad.ac.id/farmaka/v5n1/usi.pdf. Diakses 21 Maret 2015.

Sulistiawati, I Dewa Ayu Nuraini, 2011, Pemberian Ekstrak Daun Lidah Buaya (Aloe vera) Konsentrasi 75\% Lebih Menurunkan Jumlah Makrofag dari pada Konsentrasi 50\% dan $25 \%$ pada Radang Mukosa Mulut Tikus Putih Jantan, Tesis, Program Magister, Program Studi Ilmu Biomedik Program Pascasarjana Universitas Denpasar.

Suprapto AK., 2012, Efek Salep Ekstrak Metanoldan Salep Serbuk Daun Sosor Bebek (Kalanchoe pinnata (Lamk)) Terhadap Penyembuhan Luka Sayat Pada Mencit. Karya Tulis Ilmiah. Bandung: Fakultas Kedokteran Universitas Kristen Maranatha.

Suratmo, 2008, Potensi Ekstrak Daun Sirih Merah (Piper crocatum) Sebagai Antioksidan: 21-23.

Syamsuhidayat R., 2011, Buku Ajar Ilmu Bedah, EGC., Jakarta: 17.

Verawati., 2015, Uji Aktivitas Ekstrak Etanol 70\% Kulit Batang Jarak Cina (Jatropha multifida .L) Terhadap Penyembuhan Luka Terbuka Pada Tikus Putih Jantan, Skripsi, Jurusan Farmasi Universitas Muhamadiyah. Prof. DR. HAMKA.

Voight R., 1995, Buku Pelajaran Teknologi Farmasi, Alih Bahasa Soendani Noerono Soewandhi. Universitas Gajah Mada. Yogyakarta: 564. 